\title{
Classification of isolates of Vibrio harveyi virulent to Penaeus monodon larvae by protein profile analysis and M13 DNA fingerprinting
}

\author{
Morris Pizzutto, Robert G. Hirst \\ Department of Biomedical and Tropical Veterinary Sciences, James Cook University of North Queensland, Townsville, \\ Queensland 4811, Australia
}

\begin{abstract}
A total of 17 Vibrio harveyi isolates were examined for virulence to Penaeus monodon larvae and classified by total soluble protein profiles generated by sodium-dodecyl-sulphate polyacrylamide-gel electrophoresis (SDS-PAGE) under reducing conditions. Two isolates out of 17 proved to be virulent. Most isolates fell within 2 protein groups. Group I was characterised by a $42 \mathrm{kDa}$ protein and contained 8 isolates including both virulent isolates. Group II was characterised by a $40 \mathrm{kDa}$ polypeptide and contained 7 isolates. A further 2 isolates could not be assigned to either group. Isolates were further characterised by M13 DNA fingerprinting. $V$. harveyi isolates were compared to $V$. parahaemolyticus isolates and found to be substantially more diverse in genotype. This suggested high genetic diversity within $V$. harveyi. The separation of isolates into Groups I and II by SDS-PAGE was shown to be genetically based, however the 2 virulent isolates classified within Group I did not demonstrate a high genetic association. Based on the present results, it is suggested that virulent isolates within $V$. harveyi are rare and that virulence may be explained by genetic transfer of virulence factors.
\end{abstract}

KEY WORDS: Vibrio harveyi Penaeus monodon - M13 DNA fingerprinting - Vibrio virulence · Vibrio classification

\section{INTRODUCTION}

Vibrio harveyi is commonly isolated from warm near-shore marine waters, but only recently has the virulence of this species been recognised. There is a small but growing list of marine animals found to be susceptible to infection. These include common snook Centropomus unidecimalis (Kraxenberger-Beatty et al. 1990), pearl oysters Pinctada maxima (Pass et al. 1987) and penaeid prawns (Lavilla-Pitogo et al. 1990, Muir 1991).

The losses experienced by the tiger prawn Penaeus monodon industry have been the most economically important to date. Larval prawns are particularly susceptible to Vibrio harveyi succumbing to what has been termed luminescent bacterial disease (LavillaPitogo et al. 1990). This disease has been identified as a major problem in the Philippines, causing severe losses of juvenile prawns in several hatcheries (LavillaPitogo et al. 1992).
Current research is aimed at identifying the source of Vibrio harveyi in prawn hatcheries (Lavilla-Pitogo et al. 1992). However, $V$. harveyi is a commonly occurring and generally non-pathogenic marine bacterium, which appears to be rarely virulent to Penaeus monodon larvae. Virulent isolates from the Philippines are $100 \%$ lethal to $P$. monodon larvae at challenge doses of approximately 100 cells $\mathrm{ml}^{-1}$ seawater (Lavilla-Pitogo et al. 1990). Similarly a northern Australian isolate of $V$. harveyi also has been shown to be virulent at approximately 100 cells $\mathrm{ml}^{-1}$ seawater (P. Muir pers. comm.). This contrasts with other isolates which are not virulent at a challenge dose of $10^{6}$ cells $\mathrm{ml}^{-1}$ seawater (Muir 1991).

Attempts to explain the differences in virulence among isolates of Vibrio harveyi required an investigation into the relationship between virulent and avirulent isolates. Accordingly we investigated 2 virulent isolates and determined their relationship to other avirulent $V$. harveyi isolates obtained from diverse 
ecological sources. Subtyping of isolates was carried out using 2 different techniques. Bacterial proteins were analysed on the basis of differences seen on sodium-dodecyl-sulphate polyacrylamide gels under reducing conditions, which has been used successfully to subdivide other bacterial groups (Krech et al. 1988). The relationship among isolates was investigated further by comparing DNA profiles generated using an M13 probe, which has also been used successfully to subgroup bacterial species (Ryshov et al. 1988, Huey \& Hall 1989). Importantly, both of these methods provide information on the phylogenetic relationship among strains of bacteria.

\section{MATERIALS AND METHODS}

Source of micro-organisms. The study group consisted of 17 Vibrio harveyi isolates listed in Table 1. Isolate PM47666-1 had previously been shown to be highly virulent to prawn larvae (P. Muir pers. comm.). The remaining isolates derived from both clinical and environmental sources. Cultures were generously supplied by the Sir George Fisher Centre for Tropical Marine Studies, James Cook University of North Queensland, Townsville, Australia, with several belonging to the Australian Collection of Marine Microorganisms (ACMM). Isolates PM91 and 9056681 were obtained from the Oonoonba Veterinary Laboratories, Queensland Department of Primary Industry, Townsville, Australla. Isolate 301 was isolated from the haemolymph of a diseased adult Penaeus monodon prawn. Four $V$. parahaemolyticus isolates also used in this study are listed in Table 2.

Table 1 Sources of Vibrio harveyl isolates used in this study

\begin{tabular}{|c|c|}
\hline Isolate & Source \\
\hline $\begin{array}{l}1,8,12,20,45 \\
\text { ACMM } 645, \text { ACMM } 652\end{array}$ & Environmental: seawater \\
\hline PM91, 301,ACMM 648 & $\begin{array}{l}\text { Septicaemic adult tiger prawn } \\
\text { Penaeus monodon }\end{array}$ \\
\hline PM47666-1, ACMM 642 & P. monodon larvae \\
\hline $\begin{array}{l}\text { ACMM 644, ACMM } 650 \\
\text { ACMM } 656\end{array}$ & $\begin{array}{l}\text { Septicaemic adult bandna } \\
\text { prawn Penaeus esculentus }\end{array}$ \\
\hline 9056681, ACMM 643 & $\begin{array}{l}\text { Moribund barramundi } \\
\text { Lates calcarifer }\end{array}$ \\
\hline \multicolumn{2}{|c|}{$\begin{array}{l}\text { Note: ACMM (Australian Culture of Marine Micro-organ- } \\
\text { isms) 1solates and isolates } 47666-1,1,8,12 \text { and } 20 \text { courtesy } \\
\text { of Sir George Fisher Centre for Tropica] Marine Studies, } \\
\text { James Cook University. Townsville, Australia. Isolates } \\
9056681 \text { and PM91 courtesy of Oonoonba Vetennary } \\
\text { Laboratories, Queensland Department of Primary Industry, } \\
\text { Australia }\end{array}$} \\
\hline
\end{tabular}

Table 2. Sources of Vibrio parahaemolyticus isolates used in this study

\begin{tabular}{|ll}
\hline Isolate & Source \\
\hline ACMM 102 & Human infection \\
ACMM 220 & Crown of thorns starfish ACanthaster plancii \\
ACMM 666, & Environmental: seawater \\
ACMM 667 &
\end{tabular}

Virulence tests. Tests were carried out according to the method of Muir (1991). The virulence of each Vibrio harveyi isolate was tested in 3 replicate acidwashed conical flasks containing $150 \mathrm{ml}$ of autoclaved seawater which had been previously filtered $(3 \mu \mathrm{m})$ and UV-treated (wavelength $254 \mathrm{~nm}$ ) by the Australiam Institute of Marine Sciences (Townsville, Australia). The flasks were supplemented with between $5 \times 10^{4}$ and $1 \times 10^{5}$ Chatoceros gracilis diatoms $\mathrm{ml}^{-1}$ seawater as a food source for the larvae. Actively swimming, 3-d-old Penaeus monodon larvae were used in the experiment. Fifteen larvae were counted into each flask before the addition of challenge bacteria then placed on a rotary shaker operating at $100 \mathrm{rpm}$ and $28^{\circ} \mathrm{C}$ for the duration of the experiment. Bacteria were grown at $28^{\circ} \mathrm{C}$ in Tryptone Soya-broth (Oxoid, West Heidelberg, Australia) supplemented to $2 \%$ total $\mathrm{NaCl}$ $[\mathrm{TSB}(2 \% \mathrm{NaCl})]$ to late log phase. The cell concentration was determined from the absorbance of the broth culture at $640 \mathrm{~nm}$ according to Muir (1991), and $1.5 \times 10^{8}$ cells were removed, pelleted at $2500 \times g$, and washed once in sterile seawater before being added to the flasks containing the prawn larvae. This resulted in a challenge dose of $1 \times 10^{6}$ cells $\mathrm{ml}^{-1}$ seawater. The experiment was allowed to proceed for $40 \mathrm{~h}$ before numbers of surviving larvae were counted. Student's $t$ test was used to test for significant differences between the treated and control flasks at $p=0.05$.

SDS-PAGE profiling. Bacterial proteins were made soluble by the method of Krech et al. (1988) with minor modifications and separated by sodium-dodecylsulphate polyacrylamide-gel electrophoresis (SDSPAGE) under reducing conditions. Bacteria were grown overnight at $28^{\circ} \mathrm{C}$ in $\operatorname{TSB}(2 \% \mathrm{NaCl})$. One ml of the suspension was transferred to a microcentrifuge tube and the bacteria were pelleted at $12000 \times g$ for $30 \mathrm{~s}$. The bacterial pellet was washed once in PBS and then resuspended in $200 \mu \mathrm{l}$ of sample buffer containing $0.5 \%$ sodium dodecyl sulphate (SDS) (SIGMA-Aldrich, Castle Hill, Australia), 1.25\% 2-b-mercaptoethanol, $0.03 \%$ bromophenol blue, $2.5 \%$ glycerol in $15 \mathrm{mM}$ Tris $\mathrm{Cl}$ at $\mathrm{pH}$ 6.8. The suspension was then boiled for $15 \mathrm{~min}$ and centrifuged at $12000 \times \mathrm{g}$ to remove cell debris, then $10 \mu$ of the sample was used for electrophoresis. Electrophoresis was carried out using a $7.5 \mathrm{~cm}$ 
minigel (Bio-Rad Laboratories, North Ryde, Australia), with a $12.0 \%$ separating gel in SDS-running buffer (1 M glycine, $17 \mathrm{mM}$ SDS (SIGMA-Aldrich), $124 \mathrm{mM}$ Tris pH 8.3) at $200 \mathrm{~V}$. Proteins were stained in Coomassie blue $10.2 \%$ Coomassie blue, $40 \%$ methanol, $10 \%$ acetic acid); excess stain was removed by washing in a $10 \%$ ethanol, $10 \%$ acetic acid solution.

M13 DNA fingerprinting. Bacterial DNA was extracted by a modification of the plasmid-miniprep method (Maniatis et al. 1982) and the high-salt DNA extraction method (Miller et al. 1988). This method resulted in total genomic DNA being isolated which included both chromosomal and plasmid DNA. Approximately $10 \mathrm{ml}$ of a bacterial culture, grown overnight in $\mathrm{TSB}(2 \% \mathrm{NaCl})$ at $28^{\circ} \mathrm{C}$, was transferred to a $10 \mathrm{ml}$ screw-capped polypropylene tube and the bacterial cells pelleted at $2500 \times g$ for $10 \mathrm{~min}$. The cells were resuspended in $600 \mu \mathrm{l}$ of $55 \mathrm{mM}$ glucose, $10 \mathrm{mM}$ EDTA, $25 \mathrm{mM}$ Tris at $\mathrm{pH} 8.0$, to which had been added $0.3 \mathrm{mg} \mathrm{ml}^{-1}$ of lysozyme, and held on ice for $15 \mathrm{~min}$. A further $1.2 \mathrm{ml}$ of $1 \%$ (w/v) SDS was added and the cells held on ice for 5 min to facilitate cell lysis. A $1 \mathrm{ml}$ volume of saturated sodium chloride solution was added and the tube shaken for $30 \mathrm{~s}$. The solution was separated into 2 microcentrifuge tubes and centrifuged at $12000 \times \mathrm{g}$ for $5 \mathrm{~min}$ at $4^{\circ} \mathrm{C}$ to pellet precipitated proteins. The clear supernatants were removed to a $10 \mathrm{ml}$ polypropylene tube and the DNA precipitated by the addition of at least 2.5 volumes of ice-cold ethanol. The DNA was removed and washed twice in $1 \mathrm{ml}$ volumes of $70 \%$ and $100 \%$ ethanol, the ethanol was evaporated and the DNA resuspended in approximately $150 \mu \mathrm{l}$ of $\mathrm{dH}_{2} \mathrm{O}$. The quality of DNA was determined by agarose gel electrophoresis and spectroscopy. Samples with undegraded DNA and $\mathrm{OD}_{260 / 280}$ ratios greater than 2.0 were used in enzyme digests.

Approximately $5.8 \mu \mathrm{g}$ of genomic DNA was digested to completion with the restriction endonuclease Hind III (Promega, Rozelle, Australia) and separated by electrophoresis through a $25 \mathrm{~cm}, 0.65 \%$ agarose gel in tris-borate buffer $75 \mathrm{mM}$ boric acid, $2.5 \mathrm{mM}$ EDTA, $130 \mathrm{mM}$ Tris, $\mathrm{pH} 8.0$ ) at $40 \mathrm{~V}$ for $40 \mathrm{~h}$. Following electrophoresis the DNA gel was depurinated $10.25 \mathrm{~N} \mathrm{HCl}$ for $10 \mathrm{~min})$, denatured (0.5 M NaOH, $1.5 \mathrm{M} \mathrm{NaCl}$ for $60 \mathrm{~min}$ ) and neutralised (1.5 $\mathrm{M} \mathrm{NaCl}_{1} 1 \mathrm{M}$ Tris $\mathrm{pH} 8.0$ for $60 \mathrm{~min}$ ) before being transferred onto HYBOND-N nylon membrane (Amersham Australia, North Ryde, Australia) by the method of Southern (1975) in $20 x$ $\mathrm{SSC}(3 \mathrm{M} \mathrm{NaCl}, 0.3 \mathrm{M}$ sodium citrate at $\mathrm{pH} 10$ ) and cross-linked by baking at $80^{\circ} \mathrm{C}$ for $2 \mathrm{~h}$. The membrane was blocked for several hours at $45^{\circ} \mathrm{C}$ in a hybridisation oven by prehybridisation in a solution consisting of $125 \mathrm{mg}$ skim milk powder, $7.5 \mathrm{ml} \mathrm{SSPE} \mathrm{(3.1} \mathrm{M} \mathrm{NaCl,}$ $0.20 \mathrm{M}$ sodium phosphate, $25 \mathrm{mM}$ EDTA, pH 7.4), $7.5 \mathrm{ml}$ distilled formamide and $7 \%$ SDS to a total volume of $25 \mathrm{ml}$. Hybridisation was carried out overnight at $40^{\circ} \mathrm{C}$ in $20 \mathrm{ml}$ of prehybridization solution with $400 \mathrm{ng}$ of M13mp8 (Amersham, Australia) radiolabelled with $[\alpha-32 \mathrm{P}] \mathrm{dATP}$ (Bresatec, Adelaide, Australia) by the primer extension method (Wells 1988). Second strand synthesis was carried out from the forward 17 -mer universal sequencing primer (Promega) and was allowed to proceed for $15 \mathrm{~min}$ at $37^{\circ} \mathrm{C}$ before being terminated by the addition of $0.3 \%$ SSC thereby leaving the variable number tandem repeat (VNTR) region of the genome single-stranded, which is the active probe site of the genome (Vassart et al. 1987). After hybridisation membranes were washed under low stringency conditions in $2 \times \mathrm{SSC}$ and $0.1 \% \mathrm{SDS}$ at $40^{\circ} \mathrm{C}$ for $15 \mathrm{~min}$ then visualised by autoradiography with intensifying screens.

Vibrio harveyi isolates grouped by similarity of protein profile following SDS-PAGE were DNA fingerprinted. Variation within groups was calculated so that the phylogenetic relatedness of isolates grouped by protein profile could be assessed. Sharing of hybridizing Hind III fragments longer than approximately 1.0 kilo base pair ( $\mathrm{kbp}$ ) was quantified as $F$ (the proportion of shared fragments) (Lansman et al. 1981).

\section{RESULTS}

\section{Virulence tests}

Two isolates, 642 and PM47666-1, had a significant effect on larval mortality ( $\mathrm{p}=0.0010$, $\mathrm{df}=4$ ), causing $100 \%$ mortality in all replicate flasks. These were the only isolates obtained from prawn hatcheries experiencing epizootics. Confirmation of these isolates' classification as Vibrio harveyi is provided in Table 3. Larval survival associated with other isolates did not vary significantly from the controls $(\mathrm{p}>0.1161, \mathrm{df}=4$ ).

\section{SDS-PAGE profiles}

All Vibrio harveyi isolates were phenotypically characterised by comparing whole-cell soluble proteins separated by SDS-PAGE. The most useful proteins for characterisation occurred in the region between 24 and $52 \mathrm{kDa}$. Most isolates could be separated into 2 main groups based on proteins within this region with little variation within each group. Group I isolates were characterised by a protein band of approximately $42 \mathrm{kDa}$ and included both the virulent isolates 642 and PM47666-1 as well as isolates 650, 652, PM91, 645, 8 and 20 (Fig. 1, Group I isolates PM47666-1, 650, 652 and PM91). Isolate PM47666-1 expressed a unique protein of approximately $24 \mathrm{kDa}$ (Fig. 1, lane 1). Iso- 
Table 3. Characteristics used to classify isolates 642 and PM47666-1, virulent to Penaeus monodon larvae, into the species Vibrio harveyi. Characteristics of $V$. harveyi from Baumann et al. (1984)

\begin{tabular}{|c|c|c|c|}
\hline Characteristics & V. harveyi & 642 & PM47666-1 \\
\hline Straight Gram -ve rods & + & + & + \\
\hline Arginine dihydrolase & - & - & - \\
\hline Oxidase & + & + & + \\
\hline Reduction of $\mathrm{NO}_{3}^{-}$to $\mathrm{NO}_{2}{ }_{2}^{-}$ & + & + & + \\
\hline $\mathrm{O} / \mathrm{F}$ utilization of glucose & + & + & + \\
\hline Luminescence & variable & + & + \\
\hline Gas from D-glucose & - & - & - \\
\hline $\begin{array}{l}\text { Production of acetom } \\
\text { and/or diacetyl }\end{array}$ & - & - & - \\
\hline $\mathrm{Na}^{+}$requirement & + & + & + \\
\hline Growth at $35^{\circ} \mathrm{C}$ & + & + & + \\
\hline \multicolumn{4}{|l|}{ Production of: } \\
\hline Amylase & + & + & + \\
\hline Gelatinase & + & + & - \\
\hline \multicolumn{4}{|l|}{ Utilization of: } \\
\hline D-mannose & + & + & + \\
\hline Cellobiose & + & + & + \\
\hline D-gluconate & + & + & + \\
\hline D-glucuronate & + & + & + \\
\hline Heptanoate & + & + & + \\
\hline$\alpha$-ketoglutarate & + & + & + \\
\hline L-serine & + & + & + \\
\hline L-glutamate & + & + & + \\
\hline D. L-lactate & + & + & + \\
\hline Citrate & + & + & - \\
\hline L-proline & + & + & + \\
\hline$\alpha$-ketoglutarate & + & + & + \\
\hline Pyruvate & + & + & + \\
\hline D-mannitol & + & + & + \\
\hline L-glutamate & + & + & + \\
\hline$\beta$-hydroxybutyrate & - & - & - \\
\hline D-sorbitol & - & - & + \\
\hline Ethanol & - & - & - \\
\hline L-leucine & - & - & - \\
\hline$\gamma$-aminobutyrate & - & - & - \\
\hline Putrescine & - & - & - \\
\hline L-arabinose & variable & - & - \\
\hline D-galactose & variable & - weak & + \\
\hline Sucrose & variable & - weak & - \\
\hline
\end{tabular}

lates from Group II expressed a $40 \mathrm{kDa}$ protein and 2 protein bands, nearly superimposed, of approximately $36 \mathrm{kDa}$. Group II included isolates 1, 301, 643, 644, 648, 656 , and 9056681 . The $40 \mathrm{kDa}$ protein band appeared as a very strong protein band in some profiles or alternatively dissociated into 2 less intense protein bands. Both examples are evident in Fig $2 \mathrm{a}$ in alternating lanes 1 to 4 . This polymorphism was found to result from a variation in running conditions rather than actual isolate differences as seen by separating the same protein extract from isolate 644 on different SDSpolyacrylamide gel slabs (Fig. 2b). The 2 remaining isolates, isolate 45 and 12 , were polymorphic with respect to each other and to both Groups I and II in that

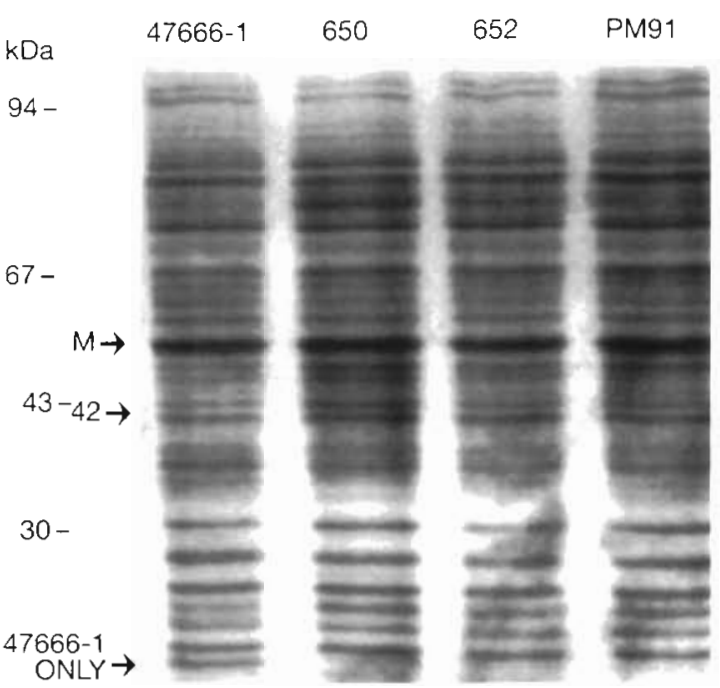

Fig. 1. Vibrio harveyi. SDS-PAGE profiles of whole-cell lysates of isolates designated as belonging to Group I. Numbers at the top refer to isolate numbers. The Group I specific protein band is labelled at $42 \mathrm{kDa}$. A protein of approximately $24 \mathrm{kDa}$ is unique to isolate PM47666-1 $\mathrm{M}: 52 \mathrm{kDa}$ major protein band. Sizes of known markers are given to the left $(\mathrm{kDa})$

they did not express the $42 \mathrm{kDa}$ or $40 \mathrm{kDa}$ proteins respectively (Fig. 3), and were thus not assigned to either group

\section{M13 DNA fingerprinting}

The M13 DNA probe hybridised to between 24 and 35 DNA fragments under the conditions used (Fig. 4 , Table 4) Six of the isolates classified in Group I, including the virulent isolates 642 and PM47666-1, were DNA fingerprinted (Fig. 4a) The average $F$ was determined to be $25.34 \%$. The average $F$-value calculated from 4 isolates with different protein profiles (unrelated group). consisting of isolates 656 (Group II); 642 (Group I); and 45 and 12 (unassigned isolates) (Fig. 4c), was marginally lower at $12.07 \%$. Within Group I, all F-values were below $39.39 \%$ with the exception of the isolate pair including the virulent 642 and the avirulent PM91 which had identical DNA fingerprints ( $F=100 \%$ ). The virulent isolate pair of 642 and PM47666-1 had an F-value of $33.33 \%$. In contrast to Group I, the 6 Group II isolates DNA fingerprinted (Fig. 4b) were substantially more related (average $F=47.22 \%$ ) than the Vibrio harveyi isolates in the unrelated group (average $F=12.07$ )

The significance of variation present in M13 fingerprints was assessed by comparing a subset of 4 Vibrio harveyi isolates, 643,644,645 and 652 (Table 1), with 4 $V$. parahaemolyticus isolates (Table 2 ). The $V$. harveyi and $V$. parahaemolyticus isolates were selected to 


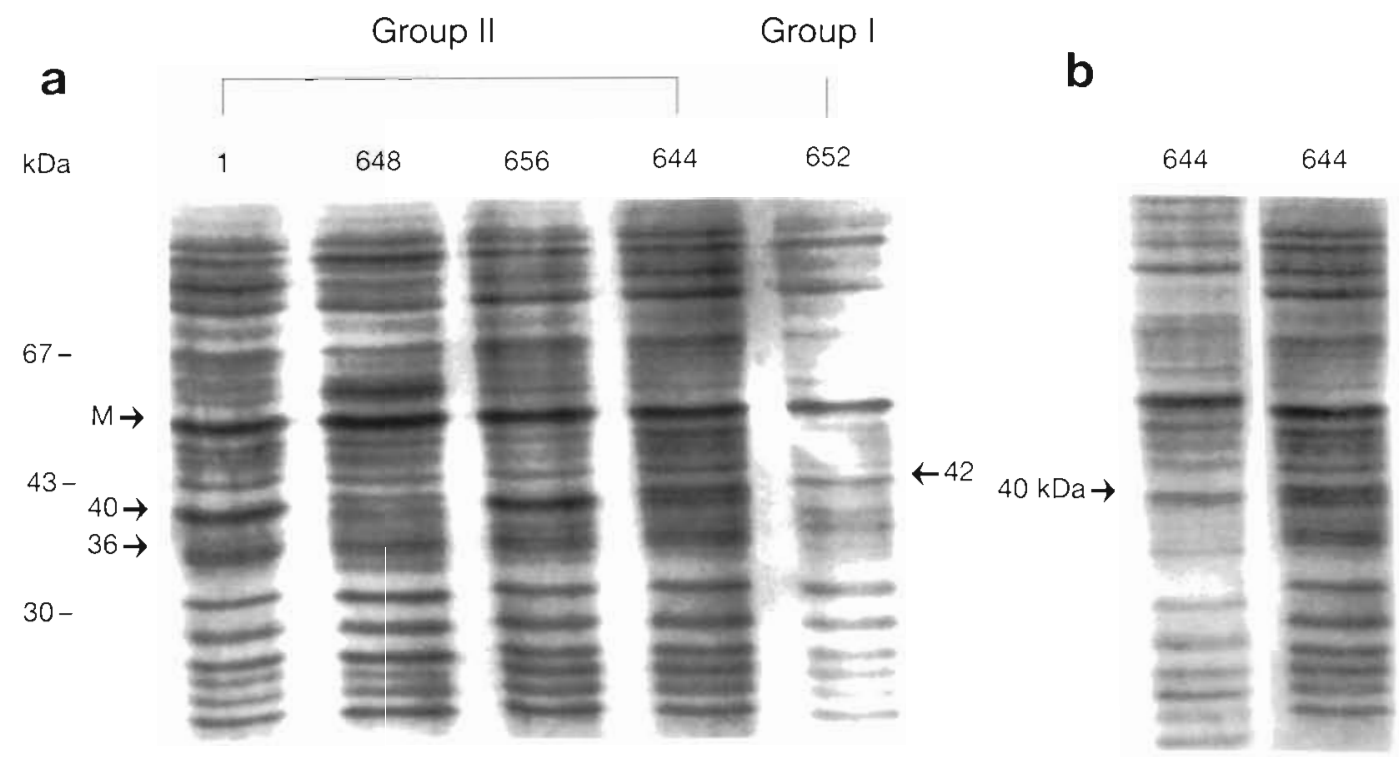

Fig. 2. Vibrio harveyi. (a) SDS-PAGE profiles of whole-cell lysates of isolates designated as belonging to Group II. Numbers at the top refer to isolate numbers. The Group 11 specific protein bands are labelled at 40 and $36 \mathrm{kDa}$. Isolate 652 demonstrating the Group I specific $42 \mathrm{kDa}$ protein band is included for comparison. M: $52 \mathrm{kDa}$ major protein band. Size of known markers are given to the left $(\mathrm{kDa})$. (b) SDS-PAGE profile of whole cell lysate of isolate 644 . Polymorphism of the $42 \mathrm{kDa}$ protein band results from minor variation in the running conditions as seen by separating the same protein extract from isolate 644 on different SDS-polyacrylamide gel slabs

include isolates diverse in origin without knowledge of protein or DNA fingerprint data. $V$. parahaemolyticus is closely related to $V$. harveyi and provided an indication of the level of genetic diversity which could be expected within these Vibrio species. Under slightly higher conditions of stringency than used previously, the $V$. harveyi isolates demonstrated a substantially lower average association when compared with the $V$. parahaemolyticus isolates (average $F=17.22 \%$ and $61.94 \%$ respectively) (Fig. 5).

\section{DISCUSSION}

The DNA probe used in this study was derived from the bacteriophage M13. It is a multilocus probe binding to regions in DNA with homology to a $15 \mathrm{bp}$ tandem repeat (Vassart et al. 1987). M13 has been used successfully to probe a wide variety of eukaryotic and prokaryotic organisms (Ryshov et al. 1988) but has only seen limited use as a phylogenetic tool with bacteria (Huey \& Hall 1989).

The variation in hybridisation patterns exhibited among isolates of Vibrio harveyi suggests that this species is genetically diverse. $V$. parahaemolyticus is closely related to $V$. harveyi (Reichelt et al. 1976, Bang et al. 1978, Brenner et al. 1983, Lambert et al. 1983) but seems to exhibit much less intra-species variation with an average $F$-value of $61.94 \%$ which is substan- tially higher than the $V$. harveyj average F-value of $17.22 \%$. Genetic variability amongst $V$. harveyi isolates was noted in earlier DNA hybridisation experiments (Reichelt et al. 1976). This may in part account for the high phenetic heterogeneity seen in $V$. harveyi when screened for their nutritional requirements (Reichelt \& Baumann 1973).

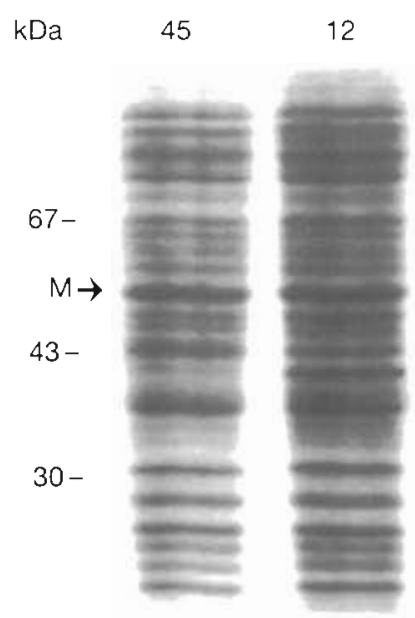

Fig. 3. Vibrio harveyi. SDS-PAGE profiles of whole-cell lysates of isolates not classified as belonging to either Group I or Group II. Numbers at the top refer to isolate numbers. M: $52 \mathrm{kDa}$ major protein band. Sizes of known markers are given to the left $(\mathrm{kDa})$ 

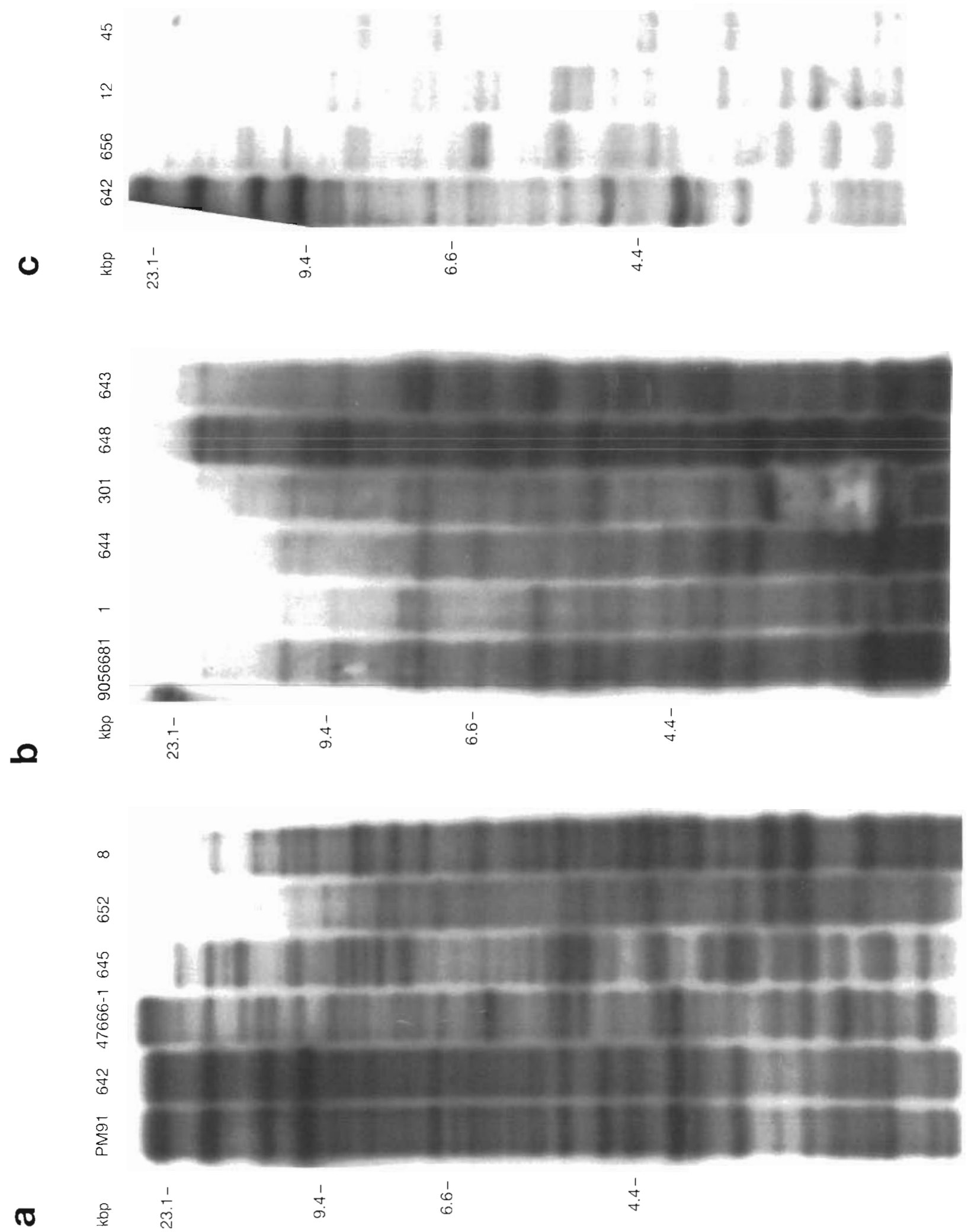

Fig. 4. Vibrio harveyl. DNA fingerprints of isolates. Genomic DNA digested with Hind III and hybridised using a radiolabelled M13 DNA probe. (a) Group I isolates; (b) Group II Isolates; (c) unrelated $V$ harveyi isolates. Size of known markers are given to the left of autoradiographs in kilo base pairs $(\mathrm{kbp})$ 
Table 4. Vibrio harveyi. Number of M13 hybridising Hind IIT. generated fragments in DNA fingerprints and average $F$-values

\begin{tabular}{|lcc|}
\hline & $\begin{array}{c}\text { No. of hybridising } \\
\text { fragments }\end{array}$ & $\begin{array}{c}\text { Average F-value } \\
(\%)\end{array}$ \\
\hline Group I & $24-30$ & 25.34 \\
Group II & $25-35$ & 47.22 \\
Unrelated isolates & $29-31$ & 12.07 \\
\hline
\end{tabular}

Fifteen of the 17 Vibrio harveyi isolates could be assigned to 2 groups based on their whole-cell protein profiles generated by SDS-PAGE under reducing conditions. These were designated Groups I and II. The phylogenetic relatedness among Group II isolates assessed by M13 DNA-fingerprinting was substantially higher compared to the unrelated isolate pairs (average F values $47.22 \%$ and $12.07 \%$ respectively). The Group I isolates appeared to be less related than the Group II isolates, even so there was a marginally higher level of relationship within this group than among the unrelated isolates (average F-values $25.34 \%$ and $12.07 \%$ respectively). It would seem, therefore, that the grouping by protein profile has a phylogenetic basis. Eight isolates fell within Group I, 7 isolates within Group II and 2 remained ungrouped. These proportions should reflect the relative proportions of these 2 groups found naturally in the environment, based on the wide diversity of sources of these isolates. If discrimination among most $V$. harveyi isolates can be achieved by differences in expression of the 42 and $40 \mathrm{kDa}$ proteins, then the groupings proposed could be used as a means of subtyping the species.

Only 2 isolates proved to be virulent to Penaeus monodon larvae despite the fact that 10 of the 17 isolates were derived from moribund prawns. Most of these clinical isolates may well have been secondary invaders only. The 2 isolates shown to be virulent to prawn larvae, PM47666-1 and 642, originated from prawn hatcheries experiencing epizootics. Isolate PM47666-1 has been recognised previously as a highly virulent strain able to cause disease at doses as low as 100 organisms $\mathrm{ml}^{-1}$ seawater (P. Muir pers. comm.).

Even though most isolates could be subgrouped, the association between virulence and phylogeny is tenuous. Both of the virulent isolates belonged to protein Group I but they were not closely related within this group $(F=33.33 \%)$. In contrast, a $100 \%$ relationship was observed between the virulent isolate 642 and the avirulent PM91, demonstrating that there would appear to be no association between virulence and the phylogenetic background of the isolates. A

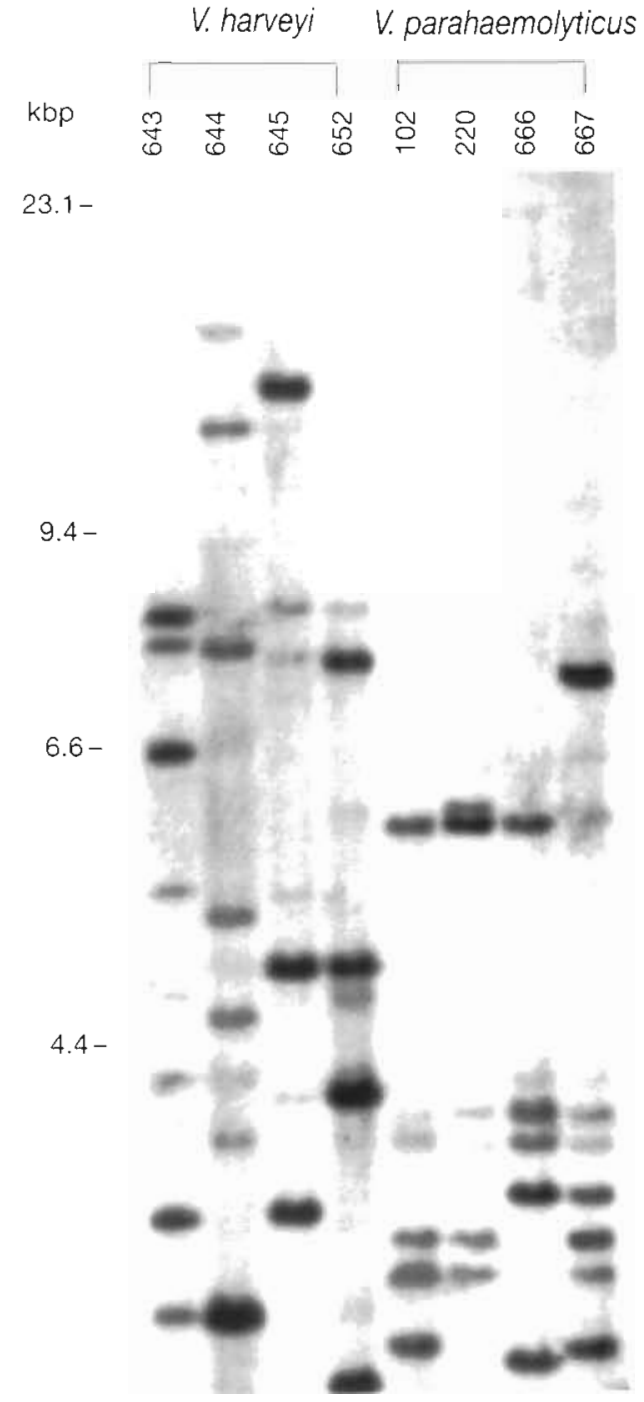

Fig. 5. Vibrio harveyi and $V$. parahaemolyticus. DNA fingerprints of isolates from diverse sources. Genomic DNA digested with Hind III and hybridised using a radiolabelled M13 DNA probe. Conditions of stringency were higher than previously used with hybridisation carried out at $45^{\circ} \mathrm{C}$. Size of known markers are given to the left of the autoradiograph in kilo base pairs ( $k b p)$

likely explanation is that isolates of Vibrio harveyi have acquired virulence factors associated with genetically mobile elements, most probably in the form of plasmids and/or transposons. Horizontal genetic transfer is a highly evolved process in bacteria and may explain why a few strains of $V$, harveyi such as isolates PM47666-1 and 642 have acquired virulence factors, even though similarly related or even highly related isolates (such as isolate PM91 with 642), do not appear to be virulent. Work is continuing to investigate whether virulence amongst $V$. harveyi strains could result from genetic transfer. 
Acknowledgements. The authors thank Peter Spencer and Ray Cocciolone for providing the opportunity to learn techniques associated with DNA fingerprinting as well as Dr D. Sutton and S. Smith, Sir George Fisher Centre for Tropical Marine Studies, James Cook University for providing most of the isolates used in this study. They also thank Dr P. Muir for information regarding Vibrio harveyi and for assistance with the pathogenicity study and Judy Forbes-Falkner of Oonoonba Veterinary Laboratories, Townsville.

\section{LITERATURE CITED}

Bang SS, Woolkalis MJ, Baumann P (1978) Electrophoretic mobilities of superoxide dismutases from species of Photobacterium, Beneckea, Vibrio, and selected terrestrial enterobactend. Curr Microbiol 1:371-376

Baumann P, Furniss AL, Lee JV (1984) Section 5. Facultatively anaerobic Gram-negative rods. Genus I. Vibrio Pacin $1854,411^{\mathrm{AL}}$. In: Holt JJ, Bergey DH (eds) Bergey's manual of systematic bacteriology, Vol I. Williams and Wilkins, Baltimore, p 518-538

Brenner DJ, Fanning GR, Hickman-Brenner FW, Steigerwalt AG, Davis BR, Farmer JJ III (1983) DNA relatedness among Vibrionaceae, with emphasis on the Vibrio species associated with human infection. In: Leclerc $\mathrm{H}$ (ed) National Institute of Health and Medical Research Colloquium, Vol 114, Gram negative bacteria of medical and public health importance: taxonomy-identificationapplications. Editions INSERM, Paris, p 175-184

Huey B, Hall J (1989) Hypervariable DNA fingerprinting in Escherichia coli: minisatellite probe from bacteriophage M1.3. J Bacteriol 171:2528-2532

Kraxenberger-Beatty T, McGarey DJ, Grier HJ, Lim DV (1990) Vibrio harveyi, an opportunistic pathogen of the common snook, Centropomus unidecimalis (Bloch), beld in captivity. J Fish Dis 13:557-560

Krech T, de Chastonay J, Falsen E (1988) Epidemiology of diptheria: polypeptide and restriction enzyme analysis in comparison with conventional phage typing. Eur J clin Microbiol infect Dis 7:232-237

Lambert MA, Hickman-Brenner FW, Farmer JJ III, Moss CW (1983) Differentiation of Vibrionaceae species by their cellular fatty acid composition. Int $J$ syst Bacteriol. 33: $777-792$

Lansman RA, Shade RO, Shapira JF, Avise JC (1981) The use of restriction endonucleases to measure mitochondrial

Responsible Subject Editor: J. E. Stewart, Dartmouth, Nova Scotia, Canada
DNA sequence relatedness in natural populations. J molec Evol 17:214-226

Lavilla-Pitogo CR, Albright LJ, Paner MG, Sunaz NA (1992) Studies on the source of luminescent Vibrio harveyi in Penaeus monodon hatcheries. In: Shariff IM, Subasinghe RP, Arthur JR (eds) Diseases in Asian aquaculture. Fish Health Section, Aslan Fisheries Society, Manila, p $157-164$

Lavilla-Pltogo CR, Baticados MCL, Cruz-Lacierda ER, de la Pena LD (1990) Occurrence of luminous bacterial disease of Penaeus monodon larvae in the Philippines. Aquaculture 91:1-13

Maniatis T, Fritsch EF, Sambrook J (1982) Molecular cloning: a laboratory manual. Cold Spring Harbor Laboratory, Cold Spring Harbor, NY

Miller SA, Dykes DD, Polesky HF (1988) A simple salting out procedure for extracting DNA from human nucleated cells. Nucl Acids Res 16:1215

Muir P (1991) Factors affecting the survival of penaeid prawns in culture with particular reference to the larval stages. PhD thesis, James Cook University of North Queensland, Townsville

Pass DA, Dybdahl R, Mannion MM (1987) Investigations into the causes of mortality of the pearl oyster, Pinctada maxima (Jamson), in Western Australia. Aquaculture 65: 149-169

Reichelt JL, Baumann P (1973) Taxonomy of the marine, luminous bacteria. Arch Microbiol $94: 283-330$

Reichelt JL, Baumann P, Baumann L (1976) Study of genetic relationships among marine species of the genera Benekea and Photobacterium by means of in vitro DNA/DNA hybridization. Arch Microbiol 110:101-120

Ryshov A.P, Jincharadze AG, Prosnyak MI, Ivanov PL, Limborsha SA (1988) M13 phage DNA as a universal marker for DNA fingerprinting of animals, plants, and microorganisms. FEBS Lett 233:388-392

Southern EM (1975) Detection of specific sequences among DNA fragments separated by gel electrophoresis. J molec Biol 98:503

Vassart G, Georges M, Monsieur R, Brocas H, Lequarre AS, Christophe D (1987) A sequence in M13 phage detects hypervariable minisatellites in human and animal DNA. Science 235:683-684

Wells RA (1988) DNA fingerprinting. In: Davies KE (ed) Genome analysis: a practical approach. IRL Press, Oxford, p $153-170$

Manuscript first received: April 12, 1994

Revised version accepted: August 29, 1994 